\title{
PENGOBATAN TRADISIONAL JAWA DALAM MANUSKRIP SERAT PRIMBON JAMPI JAWI
}

\author{
Hesti Mulyani, Sri Harti W., dan Venny Indria E. \\ FBS Universitas Negeri Yogyakarta \\ email: hesti_mulyani@uny.ac.id
}

\begin{abstract}
Abstrak
Penelitian ini bertujuan mendeskripsikan pengobatan tradisional Jawa dalam manuskrip Serat Primbon Jampi Jawi. Penelitian menggunakan pendekatan filologi modern. Sumber data penelitian adalah Serat Primbon Jampi Jawi Jilid I koleksi Perpustakaan Reksapustaka Mangkunegaran Surakarta. Hasil penelitian sebagai berikut. Pertama, pengobatan tradisional Jawa yang ditemukan adalah untuk penyakit cacingan dan disentri (berak berdarah). Kedua, bahan ramuan/resep pengobatan berupa: akar (bakung), kayu/ kulit kayu (cendana, kayu timur, dan mesoyi), daun (asam, lampes, dan trawas), buah (adas, cabe, jambe, dan pala), biji (jinten hitam dan ketumbar), bunga (cengkih dan apen), umbi (bawang putih), dan rimpang (bengle, dringo, dan temuireng). Bahan-bahan lain sebagai pelengkap adalah air tawar panas, garam, ikan kutuk, dan tajin. Ketiga, cara pengolahan ramuan/resep: (a) dibakar, (b) dikukus dalam tanakan nasi, (c) dikunyah, (d) dihaluskan/ di-pipis, dan (e) direbus. Keempat, metode pengobatan dengan caracekok (diminum) dan sembur (pengobatan luar).
\end{abstract}

Kata kunci: pengobatan tradisional, manuskrip Jawa, cekok, sembur

\section{JAVANESE TRADITIONAL MEDICAL CARE IN THE SERAT PRIMBON JAMPI JAWI MANUSCRIPT}

\begin{abstract}
This study aims to describe Javanese traditional medical care in the Serat Primbon Jampi Jawi manuscript. It used the modern philology approach. The source of the research data was Serat Primbon Jampi Jawi Volume I, a collection of the Reksapustaka Library, Mangkunegaran, Surakarta. The research findings are as follows. First, Javanese traditional medical care is found for intestinal worms and dysentery (bloody stools). Second, the ingredients/medical prescriptions are in the form of: root (narcissus), wood/bark (sandalwood, kayu timur, and mesoyi), leaves (tamarind, lampes, and trawas), fruits (anise, chili, areca nut, and nutmeg), seeds (black cumin and coriander), flowers (clove and apen), bulbs (garlic), and rhizomes (bengle, dlingo, and black curcuma). Other complementary ingredients are hot fresh water, salt, snakehead murrel, and starch. Third, herb/prescription processing methods include: (a) burning, (b) steaming in a rice steamer, (c) chewing, (d) smoothing, and (e) boiling. Fourth, the medical care methods include cekok (force-feeding) and sembur (spraying from the mouth for an external treatment).
\end{abstract}

Keywords: traditional medical care, Javanese manuscript, cekok, sembur

\section{PENDAHULUAN}

Artikel berjudul “Pengobatan Tradisional Jawa dalam Manuskrip Serat Primbon
Jampi Jawi"ini adalah bagian dari laporan penelitian kelompok tentang "Pengobatan Tradisional Jawa pada Manuskrip- 
Manuskrip Mangkunegaran, Kasunanan Surakarta, dan Museum Radyapustaka". Melalui penelitian tersebut diharapkan diperoleh: (a) deskripsi jenis pengobatan tradisional Jawa dan (b) deskripsi jenisjenis bahan pengobatan dalam manuskripmanuskrip Jawa yang tersimpan di kraton Mangkunegaran, Kasunanan Surakarta, dan Museum Radyapustaka.

Pengobatan tradisional pada awalnya merupakan tradisi turun-temurun yang disampaikan secara lisan dari satu generasi ke generasi berikutnya. Seiring dengan dikenalnya tradisi tulis, pengobatan tradisional yang awalnya merupakan oral tradition, akhirnya dituliskan. Sampai sekarang, tulisan-tulisan kuna oleh nenek moyang bangsa Indonesia tersebut tersimpan di museum-museum dan perpustakaan-perpustakaan di Indonesia dan luar negeri. Tulisan tersebut dikenal dengan sebutan naskah atau manuskrip.

Darusuprapta menjelaskan bahwa manuskrip atau naskah adalah karangan tulisan tangan nenek moyang, baik yang masih asli maupun salinannya (Mulyani, 2014:1). Jawa adalah nama pulau yang dihuni oleh masyarakat yang melestarikan suatu tradisi dari waktu ke waktu dan dilanjutkan oleh generasi penerusnya. Manuskrip Jawa adalah karangan tulisan tangan nenek moyang Jawa, baik yang masih asli maupun salinannya, berisi uraian tentang suatu tradisi (Baroroh-Baried, 1994: 1-3, 55).

Salah satu tradisi yang termuat dalam manuskrip tersebut adalah tradisi pengobatan tradisional Jawa. Tradisi pengobatan tradisional Jawa adalah pengobatan dengan menggunakan tanaman obat atau tumbuhan herbal yang diolah secara tradisional, cara penyembuhannya pun juga secara tradiional, dan diwariskan secara turun-temurun. Kegiatan tersebut tadinya hanya dikenal oleh kalangan tertentu kemudian menyebar hingga masyarakat luas, termasuk masyarakat Jawa (Redaksi Trubus, 2012: 1).
Dalam hal ini, jamu yang dimaksud adalah ramuan dari bahan racikan jamu yang berasal dari tanaman obat (tumbuhan herbal). Keberadaan tanaman sebagai obat sudah dikenal sejak ribuan tahun yang lampau. Bukti sejarah telah terukir di helaian lontar, dinding-dinding candi, dan tulisan dalam manuskrip Jawa (primbon). Manuskrip Jawa (primbon), yakni SPJJ I (Serat Primbon Jampi Jawi jilid I) mencatat pemakaian obat tradisional yang telah dilakukan oleh masyarakat Jawa. Dalam dunia tentang obat-obatan, obat tradisional jika memenuhi syaratsyaratnya dapat dimanfaatkan untuk pengobatan. Pemanfaatan obat tradisional dari tumbuhan herbal yang utama adalah untuk pengobatan tradisional (Redaksi Trubus, 2012: 7, 10).

Sampai saat ini, pengobatan dengan obat herbal ada tiga istilah yang terkait di dalamnya, yaitu obat tradisional, obat asli, dan obat bahan alam. Badan Kesehatan Dunia (WHO) mendefinisikan obat tradisional sebagai obat asli di suatu negara yang digunakan secara turun-temurun di negara itu dan negara lain (Redaksi Trubus, 2012: 10). Selanjutnya, obat asli adalah suatu obat bahan alam yang ramuannya, cara pembuatan, pembuktian khasiat, keamanan, dan cara pemanfaatannya berdasarkan pengetahuan tradisional penduduk suatu daerah. Obat bahan alam adalah semua obat yang dibuat dari bahan alam yang proses pembuatannya belum merupakan isolat murni. Obat bahan alam dapat berupa obat asli, obat tradisional, atau pengembangan dari keduanya.

Di Jawa, sampai sekarang, masyarakatnya masih memanfaatkan ramuan tradisional. Ramuan tradisional Jawa masih diyakini membantu kesulitan kesehatan terutama bagi masyarakat yang tinggal di pedesaan. Hal itu terjadi karena alam pedesaan dimungkinkan masih mudah untuk mendapatkan banyak bahan tanaman yang berkhasiat obat (Mulyani, 2015: 2). Lama kelamaan, begitu besarnya per- 
hatian masyarakat pada pengobatan tradisional maka mereka yang hidup di kota besar pun juga mulai membudidayakan tanaman obat (Hartati, 2011:22). Ramuan tradisional berbahankan tanaman obat atau tumbuhan herbal digunakan untuk pengobatan. Pengobatan itu merupakan sesuatu yang tidak dapat terlepas dari kehidupan sehari-hari manusia, baik dari pengobatan penyakit yang paling ringan maupun sampai pengobatan penyakit yang terberat.

Perkembangan ilmu pengobatan mengikuti perkembangan peradaban manusia. Oleh karena itu, semakin berkembang peradaban manusia, ternyata penyakit pun ikut berkembang pula. Faktanya, pesatnya kemajuan pengobatan hingga ditemukannya obat-obatan kimia, ternyata tidak dapat menggantikan fungsi obat herbal. Obat kimia selalu ditakuti karena efek samping yang tidak baik bagi tubuh, sedangkan obat herbal lebih aman dan nyaman digunakan oleh masyarakat. Obat herbal berbahan dasar alam atau alami itu mampu menanggulangi efek samping yang buruk (Wind, 2014: v). Sehubungan dengan hal tersebut, maka sampai saat ini pun banyak ditulis buku-buku yang terkait dengan tanaman obat tradisional, manfaat, dan ramuan yang dapat dibuat untuk mengobati penyakit-penyakit tertentu. Namun demikian, sumber-sumber rujukan belum dicantumkan pada tulisantulisan tersebut, terutama yang terkait dengan manuskrip Jawa.

Dalam khasanah manuskrip Jawa, manuskrip SPJJ I adalah termasuk manuskrip dalam pengelompokan teks sastra primbon (Behrend, 1990: xii). Kategori teks sastra jenis primbon itu memuat uraian tentang racikan jamu asli Jawa. Di samping itu, juga merupakan ungkapan pikiran dan perasaan nenek moyang sebagai hasil budaya bangsa masa lampau (BarorohBaried, 1994: 55) yang sarat dengan ajaran tentang jamu (bahan jamu, racikan, cara pengolahan, dan cara pengobatannya secara tradisional Jawa). Hal itu ditulis sebagai dokumentasi khasanah pengobatan alternatif yang telah berabad-abad dilakukan oleh masyarakat Jawa, tidak saja menarik perhatian pada bidang sosio-budaya pada umumnya, tetapi juga menarik pada bidang pengobatan tradisional.

Dengan sarana tulisan ini, demi untuk pelestarian, baik dokumen tertulis (manuskrip) maupun isi yang dikandungnya, diangkat dan dianalisis isi teksnya. Manukrip SPJJ I adalah salah satu manuskrip sebagai sumber data dalam penelitian yang sudah dan sedang dilakukan (Mulyani, 2015, 2016), dipilih untuk diangkat dan dianalisis khusus cara pengobatan tradisional Jawa, yakni cekok dan sembur untuk mengobati penyakit cacingan bagi penderita anak-anak.

\section{METODE}

Penelitian yang dilakukan menggunakan metode penelitian deskriptif dengan pendekatan filologi modern. Pendekatan filologi modern digunakan, karena penelitian ini memanfaatkan sumber data berupa manuskrip dan teks kuno. Pendekatan deskriptif digunakan karena semua hasil penelitian berdasarkan pendekatan filologi disajikan secara deskriptif atau diuraikan.

Penelitian dengan pendekatan filologi itu dilakukan berdasarkan langkah kerja penelitian filologi (Mulyani, 2015:15). Langkah kerja penelitian filologi yang dilakukan ada lima hal, meliputi: (1) inventarisasi manuskrip berdasarkan studi katalog dan pengamatan langsung di tempat penyimpanan manuskrip sebagai sumber data penelitian; (2) deskripsi manuskrip, meliputi semua hal yang berhubungan dengan keadaan fisik manuskrip; (3) alih tulis yang dilakukan adalah menulis kembali teks yang dimuat dalam sumber data dengan aksara Latin; (4) menerjemahkan teks, yakni mengalihbahasakan dari bahasa Jawa ke bahasa Indonesia dengan metode terjemahan harfiah jika mungkin 
atau metode terjemahan makna atau isi, dan jika tidak dapat dilakukan dengan kedua metode tersebut maka digunakan metode terjemahan bebas dengan memperhatikan makna secara kontekstual; dan (5) menganalisis isi teks.

Sumber data penelitian adalah Manuskrip Serat Primbon Jampi Jawi (SPPJ) jilid I. Serat Primbon Jampi Jawi Jilid I merupakan salah satu koleksi Perpustakaan Reksapustaka Mangkunegaran Surakarta dengan Kode 25655 (M 19). Manuskrip ini merupakan salah manuskrip yang memuat pengobatan tradisional Jawa, di samping manuskrip-manuskrip yang lain, seperti: (a) Serat Primbon Racikan Jampi Jawi Jilid II, (b) Serat Primbon Jampi Jawi Jilid IV, (c) Serat Memulya Sarira, dan (d) Serat Bab Tetuwuhan ing Tanah Hindiya miwah Dayanipun kangge Jampi.

Teknik analisis data yang digunakan dalam penelitian ini adalah teknik deskriptif. Langkah-langkah dalam menerapkan metode analisis deskriptif, berturut-turut (1) reduksi data, (2) klasifikasi data, (3) display data, (4) melakukan penafsiran dan mengambil simpulan (Kaelan, 2005: 68-71).

\section{HASIL DAN PEMBAHASAN Jenis Penyakit dan Bahan Ramuan}

Dalam Serat Primbon Jampi Jawi Jilid I ditemukan deskripsi beberapa penyakit yang menyerang anak-anak, orang dewasa, dan keduanya. Penyakit dan ramuan yang ditemukan antara lain: bèrèngen (penyakit kulit berwarna merah), bedhedheg (sesak di perut), bentèr (panas), cacing (cacing), endjrak (sakit gomen/sariawan/ penyakit luka-luka pada bibir), Gom (sariawan), ising-isingen (berak terus/cika).

Di antara beberapa jenis penyakit dan cara pengobatannya, salah satu jenis penyakit yang banyak dikupas dalam Serat Primbon Jampi Jawa Jilid I adalah penyakit cacingan dan cacingan yang disertai berak darah (disentri). Oleh karena itu, dalam artikel ini yang dikupas lebih terperinci adalah jenis penyakit cacingan. Deskripsi dan penjelasan mengenai berbagai macam penyakit dan cara pengobatanya disajikan secara lengkap dalam Laporan Penelian tentang "Pengobatan Tradisional Jawa pada Manuskrip-Manuskrip Mangkunegaran, Kasunanan Surakarta, dan $\mathrm{Mu}-$ seum Radyapustaka"

Temuan hasil penelitian yang berhubungan dengan racikan dan ramuan/ resep jamu untuk penyakit cacingan dengan sarana pengobatan tradisional Jawa cekokdan semburyang dimuat di dalam SPJJI disajikan pada Tabel 1.

Berdasarkan Tabel 1 tampak bahwa terdapat tiga macam racikan dan ramuan/ resep jamu tradisional untuk pengobatan penyakit cacingandan satu macam racikan dan ramuan/resep jamu tradisional untuk pengobatan penyakit cacingan disertai berak darah yang diderita oleh anak-anak.

Selanjutnya, dalam SPPJ I ditemukan cara pengobatan untuk penyakit cacingan dan cacingan yang disertai berak darah. Racikan dan ramuan/resep jamu tradisional yang didapatkan dalam manuskrip SPJJ I tersebut disajikan pada Tabel 2.

Tabel 1. Deskripsi Penyakit Cacingan dalam SPPJ I

\begin{tabular}{llc}
\hline No. & \multicolumn{1}{c}{ Nama Penyakit } & $\begin{array}{c}\text { No. Jamu/ } \\
\text { Halaman }\end{array}$ \\
\hline 1. & Cekokipun raré cacingen (Jamu cekok untuk anak sakit cacingan) & $244 / 83$ \\
2. & Cekokipun raré cacingen (Jamu cekok untuk anak sakit cacingan) & $251 / 85$ \\
3. & Cekokipun raré cacingen (Jamu cekok untuk anak sakit cacingan) & $274 / 93-94$ \\
4. & Cekok raré cacingen wawratan rah (Jamu cekok untuk anak sakit & $245 / 83$ \\
& \\
\hline
\end{tabular}

LITERA, Volume 16, Nomor 1, April 2017 
Tabel 2. Komposisi Ramuan/Resep Jamu untuk Penyakit Cacingan

\begin{tabular}{|c|c|c|c|}
\hline No. & Dekripsi Ramuan & Terjemahan & Keterangan \\
\hline 1. & $\begin{array}{l}\text { Cekokipun raré cacingen: } \\
\text { Jinten cemeng, ketumbar sami } \\
\text { wawrat } 2 \text { saga, adas sasaga, } \\
\text { kutuk satunggal kabakar, temu } \\
\text { cemeng } 3 \text { iris, kapipis dipun- } \\
\text { ombèkaken. }\end{array}$ & $\begin{array}{l}\text { Cekok untuk anak cacingan: } \\
\text { Jintan hitam, ketumbar } \\
\text { seberat @ } 2 \text { saga, sesaga adas, } \\
1 \text { ekor kutuk dibakar, } 3 \text { iris } \\
\text { temu cemeng, dihaluskan } \\
\text { diminumkan. }\end{array}$ & $\begin{array}{l}\text { Angka 244- } \\
\text { kaca 83 } \\
\text { (Angka 244-ha- } \\
\text { laman 83) }\end{array}$ \\
\hline 2. & $\begin{array}{l}\text { Cekokipun raré cacingen: } \\
\text { Godhong lampes } 1 \text { lb, godhong } \\
\text { asem sepuh, sarem } 1 \text { wuku, silit } \\
\text { bawang 1, dipunmamah lajeng } \\
\text { dipuncekokna, kaping } 3 \text { cekokan. } \\
\text { Nunten dipunsemburaken, ing } \\
\text { puser tuwin ing wingking. }\end{array}$ & $\begin{array}{l}\text { Cekok untuk anak cacingan: } 1 \\
\text { lb daun lampes, daun asam } \\
\text { tua, } 1 \text { jumput garam, } 1 \text { silit } \\
\text { bawang, dikunyah lalu di- } \\
\text { cekok-kan, untuk cekok } 3 \text { kali. } \\
\text { Kemudian di-sembur-kan, di } \\
\text { pusar dan di bagian belakang. }\end{array}$ & $\begin{array}{l}\text { Angka 251- kaca } \\
85 \\
\text { (Angka 251-ha- } \\
\text { laman 85) }\end{array}$ \\
\hline 3. & $\begin{array}{l}\text { Cekokipun raré cacingen: Oyot } \\
\text { bakung panjangipun } 3 \text { nyari, } \\
\text { ketumbar } 5 \text { saga, mesoyi } 3 \text { saga, } \\
\text { trawas } 2 \text { lb, bawang sasiyung, } \\
\text { temu cemeng } 2 \text { iris, cengkèh } 2, \\
\text { pala saklungsu, dringo } \\
\text { saklungsu, benglé } 2 \text { iris, } \\
\text { pucukipun cabé } 1 \text {, mesoyi saros } \\
\text { dariji, sekar apèn } 3 \text { saga, lajeng } \\
\text { dipunpipis toyanipun wédang } \\
\text { sarta kakukusaken ing liwet. Yèn } \\
\text { ngejèri kaliyan wédang, } \\
\text { dipunombèkna ing wanci énjing }\end{array}$ & $\begin{array}{l}\text { Cekok anak cacingan: Akar } \\
\text { bakung sepanjang } 3 \text { jari, } 5 \\
\text { saga ketumbar, } 3 \text { saga mesoyi, } \\
2 \mathrm{lb} \text { trawas, seulas bawang, } 2 \\
\text { iris temuireng, } 2 \text { buah } \\
\text { cengkèh, sebiji asam pala, } \\
\text { sebiji asam dringo, } 2 \text { iris } \\
\text { benglé, } 1 \text { buah ujungnya cabé, } \\
\text { mesoyi seruas jari, } 3 \text { saga } \\
\text { bunga apèn, lalu dihaluskan } \\
\text { sampai halus dengan air serta } \\
\text { dikukus di dalam tanakan } \\
\text { nasi. Untuk melarutkan } \\
\text { dengan air, diminumkan pada } \\
\text { waktu pagi }\end{array}$ & $\begin{array}{l}\text { Angka274- kaca } \\
\text { 93-94 } \\
\text { (Angka 274 ha- } \\
\text { laman 93-94) }\end{array}$ \\
\hline 4. & $\begin{array}{l}\text { Cekok raré cacingen } \\
\text { wawratan rah: Cendhana } \\
\text { jenggi, kajeng timur, jambé kang } \\
\text { sepuh sami wawrat } 2 \text { saga, } \\
\text { kagodhog dados satunggal, } \\
\text { toyanipun tajin kang kenthel. }\end{array}$ & $\begin{array}{l}\text { Cekok anak cacingan disertai } \\
\text { berak darah: Cendana jenggi, } \\
\text { kayu timur, jambé tua seberat } \\
\text { @ } 2 \text { saga, direbus menjadi } \\
\text { satu, dengan air tajin yang } \\
\text { kental }\end{array}$ & $\begin{array}{l}\text { Angka 245-kaca } \\
83 \\
\text { (Angka 245 - } \\
\text { halaman 83) }\end{array}$ \\
\hline
\end{tabular}

Kandungan atau Khasiat Bahan Ramuan

Pengobatan penyakit cacingan dengan pengobatan tradisional Jawa dari ramuan/ resep jamu yang ditemukan terdiri atas bahan-bahan jamu yang berupa: akar (bakung), kayu/kulit kayu (cendana, kayu timur, dan mesoyi), daun (asam, lampes, dan trawas), buah (adas, cabe, jambe, dan pala), biji (jinten hitam dan ketumbar), bunga (cengkih dan apen), umbi (bawang putih), dan rimpang (bengle, dringo, dan temuireng). Bahan-bahan lain sebagai 
pelengkapnya adalah air tawar panas, garam, ikan kutuk, dan tajin.

Bakung atau Crynum asiaticum L memiliki sejumlah kandungan kimia berupa likorina, krinidina, hemantamina, krinamina yang pada umumnya memiliki sifat analgesik (menghilangkan rasa nyeri) dan ekspektoran (peluruh dahak, mendorong mengeluarkan dahak). Di samping itu, akar tumbuhan bakung mengandung alkaloid likorin dan asetilkorin. Efek farmakologis dalam akar bakung, di antaranya berkhasiat sebagai peluruh kencing, antiinflamasi (mengurangi pembengkakan), mencegah pendarahan, peluruh keringat, peluruh muntah, sakit gigi, dan mengobati luka (http://www.indonews.co.id/1000-manfaat-tanaman-bakung-bagi-kesehatan/; Redaksi Trubus, 2012:556; http://www. smallcrab.com/kesehatan/1130-khasiattanaman-bakung). Dalam hal ini, akar bakung adalah salah satu bahan herbal yang dimanfaatkan untuk mencegah pendarahan, mengobati muntah, dan kemungkinan luka pada penyakit cacingan.

Cendana atau Santalum album memiliki efek herbal berupa alpha-santalol, betasantalol, lanceol, santanen, alpha-santaldiol, dan beta-santadiol. Kandungan di dalam cendana adalah minyak asiri, hars, dan zat samak. Kandungan alpha-santalol, beta-santalol merupakan 2 senyawa yang berhasil menekan pertumbuhan bakteri dan virus. Di samping itu, khasiat cendana dapat untuk mengobati gangguan pencernaan, radang usus besar, berak darah, infeksi saluran kemih bawah, sakit kepala, dan sakit pada dada atau sesak napas (Redaksi Trubus, 2012: 272-274; Hidayat, 2015: 92).Dalam hal ini, kulit kayu cendana adalah salah satu bahan herbal yang dimanfaatkan untuk menekan pertumbuhan bakteri dan virus serta mengobati radang usus besar, dan berak darah.

Di Jawa, secara tradisional kulit kayu mesoyi atau Cryptocarya massoia digunakan untuk menghangatkan perut pada kasus diare/murus dan kejang perut. Bau aromatis yang dihasilkannya menyebabkan bahan ini sering digunakan untuk bedak bersama-sama dengan cengkeh. Bedak itu digunakan sebagai penghangat kulit di saat hujan atau saat udara dingin. Baunya juga merangsang timbulnya hasrat seksual. Kadang-kadang kulit mesoyi ini dibakar supaya menyebabkan bau harum ke seluruh ruang (seperti layaknya kemenyan). Berdasarkan aktivitas biologi yang telah diteliti, kulit kayu mesoyi bersifat sebagai counter irritant (melembabkan pembuluh darah kapiler) dan aromatikum (bahan pewangi,digunakan sebagai campuran ratus wangi. (http:// mahkotadewa.net/kesehatan/ kayu_mesoyi.html). Dalam hal ini, mesoyi adalah salah satu bahan herbal yang digunakan untuk menghangatkan perut pada kasus diare/murus dan kejang perut pada penderita cacingan.

Asam biasanya dikenal dengan asam jawa atau Tamarindus indica memiliki kandungan vitamin B3, geranial limonene, peptin, dan sebagainya. Daun asam memiliki kandungan stexin, iovitexin, isoorietin, flavovoid, saponin,dan tanin. Khasiat daun asam adalah untuk obat bisul dan koreng, termasuk cacar. Khasiat lain dari daun asam adalah untuk mengobati encok, eksim, campak, demam, sariawan, kolesterol tinggi, asma, dan kencing manis (Redaksi Trubus, 2012: 198-200; http://manfaatbuahdaun.blogspot.co.id/ 2014/10/30-manfaat-asam-jawa-untukkesehatan.html). Dalam hal ini, daun asam adalah salah satu bahan herbal yang digunakan untuk mengobati cacingan dengan cara pengobatan di-cekok-kan (diminumkan) dan di-sembur-kan.

Daun lampes atau Ocimisancti folium berkhasiat sebagai pelancar ASI (laktagoga), emmenagoga (membersihkan, menuntaskan darah haid), karminatif (peluruh kentut, mengeluarkan angin), dan antipiretik (pereda demam) (Depkes RI, 1977 dalam Widyastuti, 2014: 248; Redaksi Trubus, 2012: 556).Dalam hal ini, 
daun lampes adalah salah satu bahan herbal yang digunakan untukmengobati jenis penyakit cacingan.

Daun trawas atau Litsea odorifera Val mempunyai bau aromatik dan rasanya kelat. Daun trawas memiliki kandungan minyak atsiri, damar, metil nonil keton, dan tanin. Daun trawas berkhasiat untuk penurun demam dan memperlancar ASI.(http://seputar-kandungan.blogspot. co.id/2012/10/mmanfaat-dan-khasiatdaun-trawas.html; http://diu.ff.unair. ac.id/obatherbal/?page=home\&view $=$ det ail\&id=246). Dalam hal ini, daun lampes adalah salah satu bahan herbal yang digunakan untukmengobati jenis penyakit cacingan.

Adas atau Feoniculum vulgare memiliki efek herbal menghilangkan nyeri, mengurangi pembengkakan, melancarkan peredaran darah, peluruh kentut, menambah nafsu makan, dan mengobati gangguan lambung. Kandungan di dalam buah adas adalah limonena, minyak lemak, minyak asiri, stigmasterol, kamfena, aponin, flavonoida, polifenol, anetol, dan sebagainya. Kandungan minyak asiri dalam buah adas berkhasiat sebagai peluruh dahak, stimulan, laksatif, diuretik, dan antiperadangan (Redaksi Trubus, 2012: 174-175). Dalam hal ini, adas adalah salah satu bahan herbal yang digunakan untukmengobati jenis penyakit cacingan.

Cabe biasanya dikenal dengan cabe jawa atau Piper retrofractum termasuk tumbuhan fitofarmaka yang memiliki efek herbal androgenik, stimulan (perangsang), analgesik (menghilangkan rasa nyeri), dan karminatif. Buah cabe memiliki kandungan zat pedas piperine, resin (kavisin), asam palmitik, minyak asiri, sesamin, dan sebagainya. Buah cabe berkhasiat untuk mengobati disentri, diare, influensa, batuk, dan menanggulangi pencernaan terganggu, dan kejang perut (Redaksi Trubus, 2012: 127-130). Dalam hal ini, cabe adalah salah satu bahan herbal yang digunakan untuk mengobati jenis penyakit cacingan.
Buah pala atau Myristica fragrans memiliki efek herbal stomakik (menambah nafsu makan, menguatkan lambung), karminatif, sedatif (penenang), dan stimulan. Kandungan buah pala adalah minyak asiri, minyak lemak, zat samak, saponin, miristinin, elemisi, pektin, hars, lamonena, asam tetradekanoid, dan asam oleanoat. Buah pala berkhasiat untuk mengobati gangguan pencernaan, seperti disentri, maag, mencret, kembung, mual, dan kejang (Redaksi Trubus, 2012: 438-439; 556; Hidayat, 2015: 295). Dalam hal ini, buah pala adalah salah satu bahan herbal yang digunakan untuk mengobati jenis penyakit cacingan.

Biji jintan (jinten) ada dua macam, yaitu jintan hitam dan jintan putih. Dalam ramuan/resep jamu untuk jenis penyakit cacingan yang digunakan adalah jinten hitam. Jintan hitam berkhasiat meningkatkan sistem kekebalan tubuh, meningkatkan jumlah produksi ASI, mengobati asma/batuk dan alergi, kanker, gangguan pencernaan, peradangan, mencegah kanker serviks, mengobati wasir, mengobati kanker payudara, sebagai bahan dengan herbal lain untuk menurunkan kolesterol, hipertensi, dan gula darah(http://www. carakhasiatmanfaat.com/artikel/khasiatmanfaat-jinten-hitam-untuk-kesehatandan-pengobatan.html). Dalam hal ini, biji jintan hitam adalah salah satu bahan herbal yang digunakan untuk mengobati jenis penyakit cacingan.

Ketumbar atau coriandrum sativum memiliki efek herbal sebagai karminatik, laktago, stomakik, antipasmodik, diuretik, digestive, decongestan, antiinflamasi, antioksidan, antibakteri, antijamur, dan diaphoretik. Biji ketumbar memiliki kandungan resin, malic, acid, alkaloid, sabinene, mircene, dan sebagainya. Khasiat biji ketumbar adalah sebagai obat masuk angin, influensa, meredakan sakit kepala/pusing, gangguan pencernaan terutama lambung, mual, haid tidak teratur, dan sariawan. Di samping itu, juga berkhasiat untuk 
mengobati wasir, menurunkan tekanan darah/hipertensi, campak, keracunan, dan radang (Redaksi Trubus, 2012: 395-396). Dalam hal ini, biji ketumbar adalah salah satu bahan herbal yang digunakan untuk mengobati jenis penyakit cacingan.

Cengkih atau atau Syzygium aromaticum memiliki efek herbal bersifat mendorong pengeluaran gas (karminatif), dan antimuntah (antiemetik). Bunga cengkih memiliki kandungan minyak volatil (eugenol, eugenil asetat, metilsalisilat, metileugenol, fenilin, karyofilin, kaempferol, kampestrol, karbohidrat, asam oleanolik, stigmasterol, vitamin, dan carvacrol. Bunga cengkih digunakan dalam pengobatan tradisional karena khasiatnya sebagai pereda nyeri, membantu memberi rasa hangat, pereda sakit gigi, mengobati campak, kolera, dan mengobati iritasi (Redaksi Trubus, 2012: 275-276). Dalam hal ini, bunga cengkih adalah salah satu bahan herbal yang digunakan untuk mengobati jenis penyakit cacingan.

Adapun umbi dari tumbuhan herbal yang ditemukan adalah bawang putih. Bawang putih meiliki efek herbal, yakni efek antibakteri, antifungi, antivirus, antitumor, dan antidiabetes. Selain itu, juga memiliki efek antikolesterol dan antitrombotik. Umbi bawang putih berkhasiat meredakan tekanan darah tinggi, nyeri kepala, maag, dan sebagai pelindung hati (Tim Penyusun, 2012: 221). Kandungan minyak asiri dalam umbi bawang putih berhasiat sebagai antithepatotoksik, yakni antioksidan dan antigen yang dapat digunakan sebagai pelindungi tubuh dari pengaruh buruk lingkungan. Kandungan organosulfida dalam umbi bawang putih berhasiat membantu hati memproses senyawa kimia beracun, termasuk senyawa kimia yang menyebabkan kanker.

Kandungan sulfur dalam bawang putih merupakan senyawa yang dapat meningkatkan dan mempercepat kegiatan membran mucus pada saluran pernapasan. Efek tersebut ikut membantu me- legakan hidung tersumbat dan mengeluarkan lendir. Kandungan phytochemical sebagai antivirus, yakni dapat membantu membunuh bakteri-bakteri dan virus penyebab penyakit (Redaksi Trubus, 2012: 222-224). Dalam hal ini, umbi bawang putih adalah salah satu bahan herbal yang digunakan untuk mengobati jenis penyakit cacingan.

Rimpang bengle atau bangle atau Zingiber cassumanar memiliki efek herbal yang bersifat antiinflamasi, ekspektoran, pencahar, membersihkan darah, karminatif, laksatif, antibakteri, dan agen antidisentri. Bangle memiliki kandungan senyawa sabinene dan terpenin (golongan antimikroba), minyak atsiri (sineol \&penin), damar, pati, tanin, enzim lipose. Rimpang bengle berkhasiat sebagai karminatif, untuk demam, perut mulas, sakit kepala, batuk, perut nyeri, masuk angin, sembelit; sakit kuning, cacingan, reumatik, kegemukan; dan mengecilkan perut setelah melahirkan (Arisandi,Yovita. 2011:21 dalam Widyastuti, 2014: 183; Redaksi Trubus, 2012: 210-212).Dalam hal ini, rimpang bengle adalah salah satu bahan herbal yang digunakan untuk mengobati jenis penyakit cacingan.

Dringo, delingoatau jeringau atau Acorus calamus memiliki efek herbal yang bersifat afrodisiak, aromatik, karminatif, ekspektoran, stimulan, sedatif, diaforetik, emmenagogue, psikotropik, dan hallusinosik. Rimpang dringo dapat mengobati demam dan nifas (Depkes RI. 1977 dalam Widyastuti, 2014: 199). Selain itu, dringo juga berkhasiatsebagai obat penenang, obat limpa, untuk mengatasi gangguan lambung, mengurangi radang tenggorokan, mengobati bronkitis, mengobati artritis, dan digunakan sebagai bahan baku kosmetika (http://alfyfee.blogspot. com/2011/07/khasiat-dlingo.html; Redaksi Trubus,2012: 344-345). Dalam hal ini, rimpang dringo adalah salah satu bahan herbal yang digunakan untuk mengobati jenis penyakit cacingan. 
Temuireng atau Curcuma aeruginosa memiliki efek herbal antelmintik atau meluruhkan/mengeluarkan cacing. Rimpang temuireng memiliki kandungan minyak asiri, tanin, kurkumol, kurkumenol, isokurkumenol, kurdion, kurkumin, dan sebagainya. Temuireng berkhasiat untuk mengobati ambien, gonorrhea, membersihkan darah setelah melahirkan, pembengkakan dan penetralisir racun dalam tubuh, peranakan turun, pencegah penularan penyakit pada bayi melalui ASI (Hariana, 2013: 382 dalam Widyastuti, 2014: 305). Selain itu, rimpang temuireng dapat digunakan sebagai obat untuk menambah nafsu makan, melancarkan keluarnya darah kotor setelah melahirkan, penyakit kulit seperti kudis, ruam, dan borok, perut mulas (kolik), sariawan, batuk, sesak napas, serta anticacing gelang dan kremi (Redaksi Trubus, 2012: 528-529). Dalam hal ini, rimpang temuireng adalah salah satu bahan herbal yang digunakan untuk mengobati jenis penyakit cacingan.

Bahan-bahan lain sebagai pelengkap ramuan/reep jamu untuk pengobatan penyakit cacingan adalah air tawar panas, garam, ikan kutuk, dan tajin. Air adalah bahan alami yang mengandung mineral. Khasiat air tawar (air masak yang sudah dingan) adalah untuk mencairkan ramuan jamu sehingga mudah pengolahannya dan kandungan alami dalam jamu herbal tidak terlalu pekat atau ekstrak (http:// www.zonanesia.net/2016/03/manfaatminum-air-putih-setelah-bangun.html). Jika campuran ramuan jamu dengan air yang sudah dipanaskan maka dapat bermanfaat untuk proses detox alami bagi tubuh. Detox merupakan cara tepat untuk mengeluarkan racun yang ada di dalam tubuh. Jadi, bahan pelengkap yang berupa cairan, yakni air tawar panas bermanfaat sebagai pengobatan tradisional (http:// manfaat.co.id/20-manfaat-minum-airhangat-bagi-kesehatan), dalam hal ini untuk pengobatan penyakit cacingan.
Garam digunakan sebagai bahan pelengkap ramuan jamu karena memiliki efek antibakterial. Dengan kandungan antibakteri, garam memiliki manfaat untuk meredakan ruam di kulit akibat alergi dan infeksi, dapat meredakan rasa sakit dan linu, dan secara alami dapat menyerap minyak dari kulit sehingga mampu mencegah timbulnya jerawat (http://kabarimbo.com/5-manfaat-garamuntuk-kulit/). Di samping itu, meminum air garam dapat digunakan sebagai obat menangkal terhadap udara atau angin buruk. Garam yang sudah dicampur dengan air dapat menghilangkan kegatalan di kulit.

Dengan memakangaram secara langsung dapat untuk mengembalikan tenaga, menyembuhkan bengkak, dapat membantu pengeluaran racun yang ada di dalam perut (http://mustahabbah.blogspot.co.id/2015/10/fakta-tentang-manfaat-garam-untuk. html).Dalam hal ini, garam adalah salah satu bahan pelengkap ramuan bahan herbal yang digunakan untuk mengobati jenis penyakit cacingan.

Ikan kutuk atau ikan gabus atau Channa striata memiliki kandungan protein, albumin, dan protein kolagen. Daging ikan kutuk berkhasiat untuk membantu pembentukkan otot dalam tubuh, mempercepat penyembuhan luka, menjaga keseimbangan cairan dalam tubuh, menyehatkan pencernaan, membantu penyembuhan luka pasca operasi, membantu mengatasi pembengkakan, dan membantu proses penyembuhan berbagai penyakit (seperti penyakit hepatitis, Infeksi paru, typhus, diabetes, stroke) (http://khasiatikankutuk. blogspot.co.id/p/blog-page_2190.html; http://manfaat.co.id/10-manfaat-ikangabus-untuk-kesehatan). Dalam hal ini, daging ikan kutuk yang sudah dibakar adalah salah satu bahan pelengkap ramuan bahan herbal yang digunakan untuk mengobati jenis penyakit cacingan.

Campuran ramuan/resep jamu lainnya yang berupa cairan adalah tajin. Air tajin 
memiliki kandungan enzim, mineral, antioksidan, serta vitamin B dan E. Selain itu, ada mikro selenium yang sangat bermanfaat untuk tubuh, khususnya bayi. Juga, sebagai zat penetral dari segala macam zat berbahaya. Air tajin beras putih berkhasiat meningkatkan energi dalam tubuh, meningkatkan sistem pencernaan, mencegah timbulnya penyakit kanker, mencegah pikun atau alzheimer, mengobati penyakit panas dalam, dan menyembuhkan penyakit sariawan, meringankan sakit tenggorokan (http://www.republika.co.id/ berita/koran/kuliner-koran/16/01/17/ o13nro1-air-tajin-kaya-manfaat; http:// www.firdaus45.com/2016/01/15-manfaatair-tajin-beras-merah-dan.html). Dalam hal ini, air tajin beras putih adalah salah satu bahan pelengkap ramuan bahan herbal yang digunakan untuk mengobati jenis penyakit cacingan.

\section{Pengolahan atau Peracikan Bahan Ra- muan}

Ramuan jamu yang diracik menjadi resep jamu, maka pengolahannya bergantung dari sifat bahan jamunya. Adapun cara pengolahan jamu dalam ramuan/ resep jamu untuk penyembuhan penyakit cacingan yangditemukan ada tujuh macam, yaitu: (1) direbus, (2) dibakar, (3) dikerik/dikerok, (4) dituangi air panas, (5) direndam, (6) dijemur, dan (7) dihaluskan/ di-pipis. Pengolahan ramuan jamu yang direbus dengan campuranair tawar panas dimaksudkan agar khasiat bahan jamu bercampur sehingga menimbulkan efek herbal yang berkhasiat untuk pengobatan. Namun, ada bahan jamu yang sebelum dicampur dengan ramuan/resep jamu, dibakar dahulu agar menimbulkan efek herbal yang bercampur dengan khasiat materi pembakaran. Dengan demikian, ada sifat jamu bila dibakar menimbulkan kekuatan manfaat untuk pengobatan.

Pengolahan bahan jamu yang lainnya adalah dengan cara dikukus dalam tanakan nasi. Hal itu dilakukan dengan maksud karena bahan jamu tidak perlu dimatangkan dengan cara dimasak langsung. Dengan dikukus bahan jamu menjadi layu dan setengah matang kemudian dicampurkan dengan ramuan jamu yang lainnya untuk pengobatan.

Untuk pengolahan bahan jamu dengan cara dikunyah dimaksudkan agar bahan jamu menjadi lembut dan airnya dimanfaatkan untuk pengobatan dengan cara diminumkan, sedangkan ampasnya dimanfaatkan untuk pengobatan dengan cara di-sembur-kan. Ada juga cara pengolahan bahan jamu yang direbus. Hal itu dimaksudkan agar kandungan bahan jamu dapat bercampur menjadi satu, sehingga lebih efektif berkhasiat untuk pengobatan. Yang terakhir, pengolahan bahan jamu dengan cara dihaluskan (dipipis) dimaksudkan agar kandungan bahan-bahan jamu dapat dimanfaatkan semuanya, sehingga didapatkan pengobatan yang efektif.

Pengolahan bahan jamu tersebut di atas adalah pengolahan yang dilakukan secara tradisional yang sudah berahuntahun dilakukan oleh masyarakat Jawa. Pengolahan bahan jamu yang ditemukan dalam SPJJ I ada yang hanya dengan satu cara pengolahan saja. Akan tetapi, ada pula ramuan/reep jamu yang diolah dengan mengkombinasikan beberapa cara pengolahan. Hal itu dilakukan demi untuk mendapatkan pengobatan yang efektif sehingga pengobatan yang diolah secara tradisional oleh masyarakat Jawa itu manjur atau ampuh untuk mengobati penyakit, baik penyakit cacingan maupun cacingan disertai berak darah bagi penderita anak-anak.

\section{Cara atau Metode Pemberian Ramuan (Pengobatan)}

Untuk metode pemberian jamu yang ditemukan dalam SPJJ I ada dua macam, yakni diminumkan dengan cara di-cekokkan dan di-sembur-kan.Oleh karena penderitanya adalah anak-anak, maka 
meminumkan jamunya dengan cara di-cekok-kan. Hal itu dimaksudkan agar takaran atau dosis jamu dapat diminum semuanya. Mengingat yang meminum jamu adalah anak-anak yang mayoritas tidak suka minum jamu, maka cara yang paling efektif adalah dengan cara di-cekokkan.

Di samping itu, pengobatan dengan ramuan jamu yang di-sembur-kan. Cara pengobatan ini dimaksudkan agar khasiat jamu dapat langsung mengena pada bagian puser dan di seluruh perut bagian depan dan belakang sehingga perut menjadi hangat. Dengan cara demikian maka semua bahan jamu untuk penyembuhan penyakit cacingan dan cacingan disertai berak darah secara langsung (di-cekokkan)dan tidak langsung (di-sembur-kan) merasuk ke dalam tubuh dan penyakitnya pun terobati.

\section{SIMPULAN}

Berdasarkan uraian di atas, dapat disimpulkan bahwa manuskrip Jawa, khususnya manuskrip SPJJ I (Serat Primbon Jampi Jawi Jilid I) memuat uraian yang berisi tentang pengobatan tradisional Jawa yang variatif untuk pengobatan penyakit cacingan yang diderita oleh anak-anak. Bahkan beberapa jenis tumbuhan yang dipilih adalah sesuai dan efektif digunakan sebagai obat/jamu penyakit cacingan, baik penyakit cacingan maupun cacingan disertai berak darah yang diderita oleh anak-anak. Hal itu terbukti dari beberapa penelitian ilmiah yang mampu membuktikan efektivitas suatu tumbuhan herbal untuk mengobati jenis penyakit cacingan. Namun demikian, pengobatan penyakit cacingan berdasarkan ramuan/resep jamu yang ditemukan dalam SPJJ I pemanfaatan pengobatannya adalah kombinasi dari beberapa tumbuhan herbal dan bahan pelengkap lainnya.

Ramuan/resep jamu yang ditemukan untuk pengobatan jenis penyakit cacingan terdiri atas bahan-bahan jamu yang berupa akar (bakung), kayu/kulit kayu (cendana, kayu timur, dan mesoyi), daun (asam, lampes, dan trawas), buah (adas, cabe, jambe, dan pala), biji (jinten hitam dan ketumbar), bunga (cengkih dan apen), umbi (bawang putih), dan rimpang (bengle, dringo, dan temu ireng). Namun, bahan-bahan jamu tersebut cara pengobatannya dikombinasikan dengan bahan-bahan lain sebagai pelengkapnya. Bahan-bahan lain sebagai pelengkap ramuan jamu untuk jenis penyakit tersebut adalahair tawar panas, garam, ikan kutuk, dan tajin).

Cara pengolahan jamu ditemukan masih tradisional, yakni dengan cara (1) dibakar, (2) dikukus dalam tanakan nasi, (3) dikunyah, (4) dihaluskan/di-pipis, dan (5) direbus. Untuk metode pemberian jamu yang ditemukannya pun juga masih tradisional, yakni dengan metode atau cara di-cekok-kan untuk meminumkan jamu yang efektif untuk penderita anakanak dan ramuan jamu yang di-semburkan pada bagian puser dan perut bagian depan dan belakang.

Berdasarkan hasil penelitian ditemukan tiga macam ramuan jamu untuk pengobatan jenis penyakit cacingan. Jika, pemanfaatan satu ramuan/resep jamu belum sembuh, maka dapat dimanfaatkan ramuan/resep jamu yang lainnya untuk penyembuhan dan seterusnya. Ramuan/ ressep jamu tersebut sudah diuji dan dituliskan dalam beberapa buku tentang ensiklopedi atau kitab tumbuhan herbal yang sudah dipublikasikan. Dengan demikian, kearifan lokal, khusus tentang pengobatan tradisional Jawa, yang terdapat dalam manuskrip Jawa dapat dimanfaatkan untuk memudahringankan kebutuhan pengobatan sehari-hari oleh masyarakat Jawa.

Oleh karena itu, disarankan perlunya dilakukan penelitian lebih lanjut dan uji farmakologi terhadap tumbuh-tumbuhan serta resep-resep pengobatan tradisional yang ditulis di dalam manuskrip- 
manuskrip, khususnya manuskrip Jawakoleksi Perpustakaan Reksapustaka Mangkunegaran Surakarta.

\section{UCAPAN TERIMA KASIH}

Melalui artikel ini, kami menyampaikan ucapan terima kasih kepada semua pihak yang berperan serta dalam penelitian tahap pertama dan tahap kedua. Artikel ini ditulis dari hasil Penelitian Fundamental dengan dana Tahun Anggaran 2015 dan 2016 dengan judul “Pengobatan Tradisional Jawa pada Manuskripmanuskrip Mangkunegaran, Kasunanan Surakarta, dan Museum Radyapustaka". Pertama, kami menyampaikan ucapan terima kasih kepada Direktorat DP2M DIKTI yang telah menghibahkan dana melalui Penelitian Fundamental. Kedua, kami menyampaikan ucapan terima kasih kepada Rektor Univeritas Negeri Yogyakarta lewat Ketua Lembaga Penelitian dan Pengabdiankepada Masyarakat UNY yang telah memfasilitasi seluruh penelitian ini. Selanjutnya, ucapan terima kasih disampaikan kepada reviewer, baik dalam seminar awal penelitian, monev internal maupun monev eksternal yang telah membaca, mengoreksi, dan memberi masukan terhadap penelitian dan artikel ini. Ketiga, ucapan terima kasih juga kami sampaikan kepada semua pihak pemberi data dan informasi serta pihak-pihak lainnya yang tidak dapat kami sebutkan satu demi satu dalam penelitian dan artikel ini.

\section{DAFTAR PUSTAKA}

Baroroh-Baried, Siti, dkk. 1994. Pengantar Teori Filologi. Yogyakarta: Badan Penelitian dan Publikasi Fakultas (BPPF) Seksi Filologi, Fakultas Sastra Universitas Gadjah Mada.

Behrend. T.E. (et.al). 1990. Katalog Induk Naskah-Naskah Nusantara: Museum Sonobudoyo Yogyakarta. Jilid 1. Jakarta: Djambatan.
Hartati, Sri. 2011. Pengobatan dengan Herbal dan Pijat Refleksi. Cara Mudah Hidup SehatAlami. Surabaya: Bintang Usaha.

Hidayat, Syamsul dan Rodame M Napitupulu. 2015. Kitab Tumbuhan Obat. Jakarta: AgriFlo.

Kaelan. 2005. Metode Penelitian Kualitatif Bidang Filsafat. Yogyakarta: Paradigma.

Mulyani, Hesti. 2014. Teori dan Metode Pengkajian Filologi. Yogyakarta: Astungkãra Media.

Mulyani, Hesti, dkk. 2015. Pengobatan Tradisional Jawa pada Manuskrip-manuskrip Jawa Mangkunegaran, Kasunanan Surakarta, dan Museum Radyapustaka. LaporanHasil Penelitian (Tahun ke-1). Penelitian Fundamental Dana DIPA UNY TahunAnggaran 2015. UNY.

Redaksi Trubus. 2012. Herbal Indonesia Berkhasiat: Bukti Ilmiah dan Cara Racik. Vol. 10.Edisi Revisi. Jakarta: PT Trubus Swadana.

Tim Pengobatan Alternatif. 2011. Obat Herbal Luar Biasa! -: CV. Pustaka Agung Harapan.

Widyastuti, Sri Harti, dkk. 2014. Fitotherapi dalam Manuskrip-manuskrip Jawa. Laporan Penelitian Fundamental Tahun Kedua Lembaga Penelitian UNY.

Wind, Ajeng. 2014. Kitab Obat Tradisional Cina. Yogyakarta: Media Pressindo.

http://alfyfee.blogspot.com/2011/07/ khasiat-dlingo.htmldiunduh: Senin, 3 Maret 2014, 10.10.

http://diu.ff.unair.ac.id/obatherbal/?page= home\&view=detail\&id=246 diunduh: Senin, 22 Agustus 2016, 06.53.

http://kabarimbo.com/5-manfaat-garamuntuk-kulit/ diunduh: Senin, 8 Agustus 2016, 09.53.

http://khasiatikankutuk.blogspot.co.id/p/ blog-page_2190.html diunduh:Senin, 22 Agustus 2016, 07.19.

http://mahkotadewa.net/kesehatan/kayu_ mesoyi.html diunduh: Senin, 3 Maret 2014, 10.00 . 
http://manfaatbuahdaun.blogspot. co.id/2014/10/30-manfaat-asam-jawa-untuk-kesehatan.html diunduh: Senin, 23 Mei 2016, 14.49.

http://manfaat.co.id/10-manfaat-ikangabus-untuk-kesehatan diunduh: Senin, 22 Agustus 2016, 07.05.

http://manfaat.co.id/20-manfaat-minumair-hangat-bagi-kesehatan diunduh: Senin, 8 Agustus 2016, 12.39.

http://mustahabbah.blogspot. co.id/2015/10/fakta-tentang-manfaatgaram-untuk.html diunduh: Senin, 8 Agustus 2016, 09.40.

http://seputar-kandungan.blogspot. co.id/2012/10/mmanfaat-dan-khasiatdaun-trawas.html diunduh: Senin, 22 Agustus 2016, 06.48

http://www.carakhasiatmanfaat.com/ artikel/khasiat-manfaat-jinten-hitamuntuk-kesehatan-dan-pengobatan. html diunduh: Senin, 3 Maret 2014, 09.40 .

http://www.firdaus45.com/2016/01/15manfaat-air-tajin-beras-merah-dan. html diunduh: Senin, 22 Agustus 2016, 07.48 .

http://www.indonews.co.id/1000-manfaat-tanaman-bakung-bagi-kesehatan/ diunduh: Jumat, 13 Mei 2016, 06.50.

http://www.republika.co.id/berita/koran/ kuliner-koran/16/01/17/o13nro1-airtajin-kaya-manfaat diunduh: Senin, 22 Agustus 2016, 0742.

h t t p://www.smallcrab.com/ kesehatan/1130-khasiat-tanamanbakung diunduh: Jumat, 13 Mei 2016. 07.02

http://www.zonanesia.net/2016/03/manfaat-minum-air-putih-setelah-bangun. html diunduh: 